Öğretmen Yetiştirme Alanı Derleme Makalesi

\begin{tabular}{l|l} 
Received & 27.06 .2016 \\
\hline Accepted & 27.07 .2016
\end{tabular}

\begin{tabular}{l|l} 
Accepted & 27.07 .2016
\end{tabular}

\title{
Cumhuriyetin erken döneminde yurt dışı eğitiminde karşılaşılan sorunlar (1923-1940)
}

\author{
Cengiz Aslan
}

Ankara Üniversitesi Eğitim Bilimleri Fakültesi, Ankara, Türkiye, cngzaslan@ gmail.com

ÖZ Bu çalışmada ulaşılan bilgi ve belgeler çerçevesinde Cumhuriyetin erken döneminde yurt dışına gönderilen öğrencilerin yurt dışında yaşadıkları sorunlar ele alınmıştır. Araştırma nitel bir araştırmadır. Araştırmanın yöntemi, nitel araştırma yöntemlerinden biri olan tarihsel araştırmadır. Yurt dışına gönderilen öğrencilerin sorunları iç ve dış faktörler olarak sınıflandırılmıştır. Öğrenim için gönderilen ülkenin sosyal, siyasal, ekonomik koşulları (ekonomik kriz ve savaş), üniversite - okuldaki işleyiş, öğrenim planları ve süreleri, paralarını zamanında alamamalarının sonucu karşılaşılan maddi sorunlar gibi faktörler dış faktörleri oluştururken; yaş ve cinsiyet farklılıkları, dil problemleri, okula ve çevreye yönelik tutumlar, derslerden başarısızlık, sağlık sorunları, evlilik ve ailevi sorunlar gibi sebepler ise iç faktörleri oluşturmaktadır. Sorunların bazılarının çözümüne yönelik elçilik, müfettiş ve ilgili okul idaresi ile yapılan yazışmalar sonucunda düzenlemeler yapılmışsa da karşıllaşılan bu sorunların planlanan ve bütçe ayrılan yurt dışı eğitim sürecinin uzamasına ve yurt dışı eğitiminde çeşitli aksaklıklar yaşanmasına neden olduğu söylenebilir.

\section{The problems of the students studying abroad in the early periods of the Republic (1923-1940)}

ABSTRACT In this study the problems of the students who were sent to abroad in the early years of the Republic are analysed within the scope of accessible data and documents. In this qualitative study the method is determined as historical research method. The students' problems are classified as internal and exogenous factors. Exogenous factors consist of social, political and economical situations (economic crisis and wars) of the country which students were sent to and organization at university/school, educational programmes and durations, financial difficulties resulting from not receiving their money on time; internal factors include age and gender differences, language problems, attitudes towards school and environment, failure in courses, health problems, family affairs. New arrangements were made after correspondence among embassy, inspector and school administration aiming at solving some of the problems but it can be stated that the problems encountered lead to extension of time in the planned studying abroad and the various breakdowns.

Keywords Study abroad, Europe, student, and problems 


\section{EXTENDED SUMMARY}

In Turkey, during the early periods of republic a western style society was prepared with Atatürk's Revolutions. Certainly, regulations in the education system are one of the important arrangements to adapt new society in this period. During this period foreign experts were invited to country and students were sent to foreign countries in order to create "new citizen" in the adaptation period from empire to republic. Sending students to grow up "national distinguishes" in foreign countries were seen the most important component of contemporary civilizations.

In this framework, students were sent to different countries. Although a few number of students were sent abroad in the first years of the Republic, later this number increased. In the early period (19231940), students were sent to Germany, France, Belgium, Switzerland, England, Austria, Italy, Czechoslovakia, Hungary, Sweden, USA and Russia.

In the current study, problems of the students, who went to abroad in the early period of the Republic, in abroad have been defined with collected documents.

This study which analyzes the problems of the students studying abroad in the early periods of the Republic (1923-1940) is a qualitative study. The historical method, which is one of the methods used in qualitative researches, was used. The documents reviewed include written records from National Education Ministry, student files and qualification cards in various units of the Ministry, correspondences among the units, official reports, decisions taken by the National Education Committee, the programs and reports of Cumhuriyet Halk Partisi (Republican People's Party), written records of Ottoman and Republican periods which are available in the General Directorate of State Archives, TBMM library, Turkish Historical Society, National Library, libraries on university campuses, various libraries and studies on the issue (dissertations, books, journals, articles, newspapers, etc.). The documents reviewed for this study have been subjected to descriptive analysis. In descriptive analysis "data is summarized and interpreted according to pre-defined themes" (Yıldırım and Şimşek, 2005).

The problems of the students in abroad in this period have been investigated in two main dimensions as internal factors (caused by individual problems) and exogenousfactors (caused by external reasons). Social, political and economical conditions of the country (economic crisis, war); university mechanism, teaching plans and durations, economical crisis caused by the late transfer of money to students are external problems. On the other hand, age and gender differences, language problems, attitudes toward school and society, low achievement, health problems, marriage and family problems composed the internal problems.

One of the main problems, as also reflected in inspector and embassy's reports, is being young and having low maturity, which is one of the internal factors. Secondly, language problems and failure in courses, adaptation problems to school and society can be listed. Thirdly, students' economical difficulties due to the late transfer of money can be counted. As a result, their debt problems, court related issues, healthy struggles aroused. Social, political and economical conditions of the country (economic crisis, war), in which all these three external factors included, is the fourth problem students faced. This is an important problem and it caused increase or decreases in students' loan or withdrawing from the program.

Another problem is budget allowed for these students. Ministry allowed more budget comparing to cities and municipalities.

Fifth external problem is teaching plans of the university. Its effectiveness changed depending on whether if there was a preparation class, the number of breaks in a teaching-learning year, university credits system, advisor, failing in courses and attendance problems.

Lastly, some internal factors as health problems, death, family problems, and marriage were other important problems. Although students were required to take a health certificate before mobility, some health problems they lived abroad caused their break off. Some of the student application to get more loans accepted while the Ministry of Education refused some others.

Some of the problems were solved with letter exchange with school administration and embassy, inspectors. Although some problems were faced in such a complex and complicated process as student sending to foreign countries, this implication continued and students were sent regularly to foreign countries. 
"Peace at home peace in the world" principle of the new Republic resulted in following new regulations in other countries, taking worthwhile applications to the country. Countries and / or cities were selected according to its quality and capacity to meet the needs of students and the Republic. 


\section{GİRIŞ}

Cumhuriyetin erken döneminde Batı model alınarak sürdürülen modernleşme düşüncesinin sonucunda öğrenim görmek için yurt dişına öğrenciler gönderilmiştir. Cumhuriyetin toplumsal yapıs1 ve kurumlarının inşa edilmesi sürecinde, "Avrupa'daki irfan mekteplerine" öğrenci gönderilmesi muasır medeniyetlerin bilgilerinin aktarılmasında en etkili yol olarak kabul edilmiştir. Yurtdışı eğitimi, 1929 yılında çıkarılan 1416 sayılı kanundan önce belirli talimatnamelerle uygulanmıştır. Öğrencilerin karşılaştıkları sorunlar ve yurt dışına gönderilmesi sürecinde yaşananlara yönelik olarak müfettiş ve elçilerden gelen raporların sonucunda yeni uygulamalar yürürlüğe konulmuştur. Bu çerçevede belirli aralıklarla talimatnameler, kararnameler yayımlanmıştır. 1922 yılında yurt dışına öğrenci gönderilmesine yönelik bir kanun taslağı hazırlanmıştır. Yurt dışına öğrenci gönderilmesinde Cumhuriyet ile birlikte 1924 ve 1927 y1lında talimatnameler, 1929 yılında ise bugün de birkaç maddesi değiştirilen 1416 Sayılı Kanun ile yasal düzenlemeler gerçekleştirilmiştir. Bu talimatnameler ve kanunda yurt dışına öğrenci gönderilmesi süreci, öğrencilerin teftişlerinin nasıl olacağı, öğrencilerin gittikleri ülkelerde ve döndüklerindeki sorumluluklarının ve haklarının neler olduğuna ilişkin ayrıntılı bilgiler yer almaktadır.

Yurt dışına öğrenim için 1923-1940 tarihleri arasında A'dan Z'ye 102 alandan 12 ülkeye öğrenci gönderilmiştir. Öğrenci gönderilen ve bulunan ülkeler sırasıyla Almanya, Fransa, Belçika, İsviçre, Amerika, İngiltere, İtalya, Avusturya, Çekoslovakya, Macaristan, İsveç ve Rusya olmuştur. Yurt dışındaki öğrencilerin teftişleri elçilikler ve Avrupa öğrenci müfettişleri aracılığıyla gerçekleştirilmiştir. Yurt dışındaki öğrencilerin teftişleri öğrenci sayısının fazlalığı ve müfettiş sayısının azlığı nedenleriyle her bir bölgeye bir müfettiş ve yardımcı görevlendirilebilmiştir. Öğrenci müfettişlikleri 1934 yılına kadar Paris ve Berlin bölgeleri olarak ikiye, bu tarihten itibaren Amerika'nın da eklenmesiyle üçe ayrılmıştır. Paris bölgesinin sorumluluk sahasında olan ülkeler, Fransa, İngiltere, Belçika, İtalya ve İsviçre; Berlin bölgesinin ise Almanya, Avusturya, Macaristan, Çekoslovakya, İsveç’tir. Amerika ise başlı başına bir bölge olmuştur (Aslan, 2014).

Cumhuriyet kurulduğunda, ülkedeki müfettiş sayısı 6'dır. 1924 yılında bu sayı 15'e çıkarılmıştır (Maarif Vekâleti İhsaiyat Mecmuası, 1927). Ülkedeki sınırlı sayıdaki müfettişlerle yurt dışındaki öğrencilerin denetlenmesi işlerinde de sorunlar yaşanmasının kaçınılmaz olduğu söylenebilir. 1925 yılında müfettiş Zeki Mesud Bey'in raporunda, Avrupa'nın çeşitli ülkelerinde bulunan öğrencilerin tek bir müfettiş tarafından sağlıklı bir şekilde teftiş ve kontrol edilemeyeceğinden bahsedilmektedir (Başbakanlık Cumhuriyet Arşivi [BCA], 180.09.0.0 / 34.181.1). Benzer biçimde Berlin Büyükelçiliği’nin 29 Aralık 1926 tarihli raporuna göre de, hiçbir öğrencinin okula devam edip etmediği, derslerine çalışıp çalışmadığının teftiş edilmediği, Almanya'da sayısı, cinsi, yaşadığı yeri, öğrenimi bilinmeyen bazı öğrencilerin olduğu belirtilmektedir (BCA, 30.10.0.0/141.9.14). Bu sorunun 1929 yılında yapılan yasal düzenlemeye kadar devam ettiği, ancak istenilen verimin elde edilemediği söylenebilir. 1933 yılında ülkedeki 26 müfettişin 2'si yabancı ülkelerde öğrenci müfettişliği yapmaktadır (Milli Eğitim Bakanlığı, 1977). Dolayısıyla sınırlı sayıda müfettişle bu sürecin kontrol edilebilirliği sorununun uzun süre devam ettiği sonucuna ulaşılabilir.

Tanzimat döneminde başlayıp, günümüzde de devam eden bir süreç olan yurt dışına öğrenci gönderilmesi, ihtiyaç duyulan insan gücünün yetiştirilmesinde önemli bir yere sahiptir. Buna karşın, Cumhuriyet tarihi ile ilgili çalışmalarda yurt dışı eğitimine ilişkin çalışma sayısı oldukça sınırlıdır. Ayrıca mevcut çalışmalarda, Cumhuriyetin erken döneminde yurt dışında yaşayan öğrencilerin yaşadıkları sorunların neler olduğuna ilişkin bir değerlendirmede bulunulmayışı bu çalışmayı önemli kılmakta ve günümüz yurt dışına öğrenci gönderilmesi süreci için de önemli veriler sağlamaktadır. $\mathrm{Bu}$ araştırmada, ulaşılan belge ve bilgiler çerçevesinde, Cumhuriyetin ilk yıllarında çeşitli ülkelere öğrenim için gönderilen öğrencilerin yurt dışında karşılaştıkları sorunlar belirlenmeye çalışılmıştır. Yurt dışına gönderilen öğrencilerin sorunları kendilerinden kaynaklanan (iç faktörler) ve kendi kontrolleri dışında (dış faktörler) gelişen bir süreç olarak iki boyutta değerlendirilmiştir. Öğrenim için gönderilen ülkenin sosyal, siyasal, ekonomik koşulları, üniversite - okuldaki işleyiş, öğrenim planları ve süreleri, paralarını zamanında alamamalarının sonucu karşılaşılan maddi sorunlar gibi faktörler dış faktörleri oluştururken; yaş ve cinsiyet farklılıkları, dil problemleri, okula ve çevreye yönelik tutumlar, derslerden başarısızlık, sağl1k sorunları, evlilik ve ailevi sorunlar gibi sebepler ise iç faktörleri oluşturmaktadır. 


\section{Yurt Dışı Eğitimiyle İlgili Tartışmalar}

Yurt dışına öğrenci gönderilmesiyle ilgili tartışmalar, Meşrutiyet ve Cumhuriyetin erken döneminde yayımlanan dergi ve gazetelere konu olmuştur. Meşrutiyet dönemi eğitimcilerinden Sâtı Bey öğrenci seçimi ve gönderiminde esaslı bir program yapılmadığını, birkaç gün içinde öğrencilerin sınava tabi tutulduğunu, sınavda ise Fransızca'dan başka bir bilgi aranmadığını, hatta öğrencilerin mesleğe ilgileri ve hazırlıklarına bakılmaksızın seçim yapıldığını belirtmiştir. Ayrıca öğrencilerin amaçlarının, Avrupa'ya gitmek ve Avrupa üniversitelerinden bir diploma almak olduğu, ne suretle olursa olsun gidelim, sonra çaresini buluruz düşünceleri içerisinde, sevmedikleri bir mesleğe aday olmak istedikleri yönünde olduğunu söyleyerek bu konuda eleştiri ve değerlendirmelerde bulunmuştur (Ünal ve Birbudak, 2010).

Cumhuriyetin erken döneminde ise, yurt dışında öğrenim görmüş olan eğitimcilerin dönemin Maarif Vekâleti Mecmuası'nda yurt dışı eğitimine ilişkin değerlendirmelerine rastlanabilir. Örneğin; Sadrettin Celal, yurt dışı eğitimi ile ilgili, öncelikli olarak ihtiyaçları belirlemek gerektiğini, daha sonra öğrenim için gidilecek yerlerin iyi belirlenmesi, gönderilecek gençlerin yalnız malumatlarının değil, aynı zamanda kabiliyet ve zekası, hürriyet ve kişiliğinin ciddi biçimde incelenmesi gerektiğini belirtmiştir. Ayrıca gönderilen öğrencilere yeterli derecede ücret verilmesi gerektiğini de vurgulamıştır. Yurt dış1 eğitiminin ise, maarif programını çizecek uzmanların araştırma, inceleme ve uygulama seyahatleri ile doğrudan doğruya maarifin çeşitli sahalarında uzmanlar yetiştirmek biçiminde iki türlü olarak yapılmasını istemiştir (Maarif Vekâleti Mecmuası [MVM], 1926). Dönemin eğitimcilerinden, yurt dışında öğrenim görmüş ve öğrenci müfettişi de olmuş olan Cevat Dursunoğlu, Cumhuriyetten sonra birçok gencin kayırma yoluyla öğrenim için Batı'ya gönderildiğini, bunların çoğunun başarılı olamadıkları halde dönüşlerinde üniversiteye alındıklarını belirtmiştir (Akyüz,2008). Dönemin İstanbul milletvekili Alâettin Cemil, Avrupa'ya öğrenci gönderme meselesini, kurtuluş inkılâbının bir aracı olarak görmekte ve Avrupa'daki ilerlemelerin bilgisine sahip olmak için, Avrupa'ya öğrenci göndermenin en kestirme ve en makul bir çözüm olduğunu söylemektedir. Böylelikle hem yabancı öğretmen meselesini, hem de üniversitelerin uzun bir sürede veremeyeceği ilim ve irfanın verilebileceğini düşünmektedir (Cumhuriyet, 1933). Bu tür tartışmaların dışında 1930 yılında yapılan müfettişler toplantısındaki önerilere bakıldığında öğrenci gönderilmesinde, her sene görülen ihtiyaca göre öğrenci gönderildiği, bunun yerine gelecekteki ihtiyaca göre öğrenci gönderilmesi gerektiği belirtilmiştir (MVM,1930). Ziyaeddin Fahri (1940) ise, Avrupa'ya gönderilen öğrencilerin çoğunlukla orta öğrenimini bitirenlerden oluştuğunu, müsbet ilim kurumlarına güvensizlik yüzünden gönderildiklerini savunmaktadır. Ayrıca Avrupa'yı hocası ve lisanı ile ayağımıza getirttiğimiz halde neden hala Avrupa'ya öğrenci gönderilmesi kaygısıyla boş yere uğraşıldığ 1 eleştirilerinde bulunmaktadır. Ancak bunun Avrupa'ya radikal bir yüz çevirme olmadığını, teknik ve fikir eğitimi alma noktasında yüz çevrilemeyeceğini belirtmektedir.

Yurt dışı eğitimiyle ilgili tartışmaların çalışma kapsamındaki tarih aralığında çeşitli boyutlarıyla tartışıldığı ve bazı düzenlemeler yapıldığı söylenebilir. Öğrencilerin karşılaştıkları sorunların çözümüne yönelik, müfettiş raporlarının sonucunda zaman zaman yeni uygulamalar yürürlüğe konulmuştur. $\mathrm{Bu}$ çerçevede belirli aralıklarla talimatnameler, kararnameler yayımlanmıştır. Ancak tartışmalarda da görüleceği üzere sosyal, ekonomik, siyasal, yönetsel, kişisel vb. birçok boyutu olan bir sürecin işleyişinde yapılan yeni düzenlemeler, sorunların yaşanılmasını önleyemese de sürecin daha iyi işletilmesinde önemli adımlar olarak değerlendirilebilir.

\section{YÖNTEM}

$\mathrm{Bu}$ araştırma nitel bir araştırmadır. Araştırmanın yöntemi, nitel araştırma yöntemlerinden biri olan tarihsel araştırmadır. Tarihsel araştırmalar, geçmiş bir zamanda ol(uş)muş eylem ya da olayların anlaşılması için tanımlama ve açıklama amacına yönelik sistematik biçimde veri toplama ve değerlendirme çabası olarak tanımlanabilir (Fraenkel, Wallen \& Hyun, 2012). Araştırmanın deseni ise tarihsel araştırma desenlerinden biri olan durum (vaka) çalışmasıdır. Durum çalışması, tarihteki herhangi bir fenomeni örnekleyebilecek bir durumu derinlemesine inceleyerek, tarihsel bir soruna 1 şı tutmay1 amaçlar (Lundy, 2008). 


\section{Verilerin Toplanması}

Çalışma kapsamında Milli Eğitim Bakanlığı arşivinde bulunan bilgi ve belgeler, Bakanlığın çeşitli birimlerinde bulunan öğrenci ve personel dosyaları, birimler arası yazışmalar, tutanaklar, dönemin Milli Talim ve Terbiye Heyeti kararları, Cumhuriyet Halk Partisi'nin program ve raporları, Başbakanlık Devlet Arşivleri Genel Müdürlüğü bünyesindeki Osmanlı ve Cumhuriyet Dönemi arşiv belgeleri, çeşitli kuruluşların kütüphaneleri ve konu ile ilgili yapılan çalışmalar (tez, kitap, dergi, makale, gazete vs.) taranmıştır.

\section{Verilerin Analizi}

Çalışma kapsamında yer alan dokümanlar, betimsel analiz yaklaşımına göre incelenmiştir. Betimsel analiz yaklaşımına göre "önceden belirlenen temalara göre elde edilen veriler özetlenir ve yorumlanırlar (Yıldırım ve Şimşek, 2005). Bu çerçevede yurt dışına gönderilen öğrencilerin yurt dışında karşılaştıkları sorunlar, ulaşılan belge ve bilgiler çerçevesinde betimlenmeye ve değerlendirilmeye çalışılmıştır. Yurt dışına gönderilen öğrencilerin sorunları iç ve dış faktörler olarak sınıflandırılmıştır. Öğrenim için gönderilen ülkenin sosyal, siyasal, ekonomik koşulları (ekonomik kriz ve savaş), üniversite - okuldaki işleyiş, öğrenim planları ve süreleri, paralarını zamanında alamamalarının sonucu karşılaşılan maddi sorunlar gibi faktörler dış faktörleri oluştururken; yaş ve cinsiyet farklılıkları, dil problemleri, okula ve çevreye yönelik tutumlar, derslerden başarısızlık, sağlı sorunları, evlilik ve ailevi sorunlar gibi sebepler ise iç faktörleri oluşturmaktadır.

\section{BULGULAR}

Bu bölümde, çalışma kapsamından ulaşılan dokümanlardan elde edilen bulgulara yer verilmiştir.

\section{Diş Faktörler}

\section{Öğrenci Gönderilen Ülkenin Sosyal, Siyasal ve Ekonomik Koşulları}

Çeşitli ülkelere öğrenim görmek için gönderilen öğrencilerin gittikleri ülkenin sosyal, siyasal ve ekonomik koşullarında meydana gelen değişikliklerin sonucu olarak doğrudan etkilendikleri söylenebilir. Bu çerçevede öğrenci gönderilen ülkenin yaşam koşulları (sosyal-ekonomik) ve ülkenin siyasal ikliminde yaşanan krizler sonucunda öğrencilerin öğrenimleri olumsuz etkilenmiştir. Örneğin; 27 Ocak 1925 tarihli Berlin Büyükelçiliği’nden gelen rapora göre İtalya'da hayat son derece pahalıdır ve öğrenciye verilen para ancak geçimlerine yetecek kadardır (BCA, 180.9.0.0 / 34.181.1). Benzer biçimde 1927 yılında Ali Şakir ve İzzet Hakkı, Demiryolları ve köprü mühendisliği öğrenimi görmek üzere Prag'a gönderilmiştir. Başarılı öğrenci oldukları için Çekoslovakya hükümeti tarafından öğrenim masrafları karşılanmıştır. Ancak ülkede meydana gelen ekonomik kriz nedeniyle, 1932'den itibaren masrafları karşılanamamıştır. Bu durum sonucunda öğrencilerin Nafia Vekâleti (Bayındırlık Bakanlığı) hesabına alınmaları kararlaştııılmıştır (Talim ve Terbiye Kurulu Kararı [TTKK], 1932).

Maarif Vekili Hasan Âli Yücel'in Başvekâlet Yüksek Makamına yazdığı bir yazıda belirtildiği üzere, II. Dünya Savaşı'nın başlaması üzerine 1939 yılında Fransa ve Almanya'da bulunan öğrenciler geri çağrılarak tamamı yurda dönüş yapmıştır (BCA, 30. 10.0.0 /142.14.8). İsviçre, İtalya, İngiltere ve Belçika'da devlet öğrencilerinden fen ve teknik sahada öğrenim görenlerin öğrenimlerine devam etmelerine, bu alanların dışındakilerin yurda dönmesine; Amerika'da öğrenimde bulanların hangi alandan olursa olsun öğrenimlerine devam etmeleri istenmiştir. Maarif Vekâleti’nin bu istek yazısında Fransa ve Almanya'dan başka ülkelerde kendi hesaplarına öğrenim görenlerin ailelerinin, yoksa kendilerinin istekleriyle bu ülkelerde öğrenimlerine devam edebilecekleri belirtilmiştir. Belçika ve Fransa'da, Sümerbank ve Maden Tedkik ve Arama Enstitüsü hesabına öğrenim görürken, Savaş nedeniyle geri çağrılan, yirmi bir öğrencinin aynı branşlarda öğrenimlerini tamamlamak üzere Amerika'ya gönderilmesi kararlaştırılmıştır (BCA,30.10.0.0 / 142.13.20.3).

Almanya'daki siyasi durum öğrencilerin tüm yaşamlarını etkilediği gibi, kaldıkları konutları değiştirmelerine de neden olmuştur. Müfettiş raporlarına göre İngiliz uçaklarının Berlin ve diğer şehirlere saldırıları sonucu bazı öğrenciler, kaldıkları konutların zarar görmesiyle evlerini değiştirmek durumunda kalmışlardır. Öyle ki, gece yapılan saldırılar sonucunda sığınaklara inme mecburiyeti karşısında, 3-4 saat uykusuz kalmak yüzünden öğrencilerin erken kalkıp okula gitmesi güçleştiği için, bütün okulların, saldırının yapıldığı gecelerin sabahında iki saat geç açıldığı bildirilmektedir. Öğrencilerden bazıları ülkenin siyasi vaziyeti sonucu tutuklanmışlar, üç öğrenci hastalıkları yüzünden 
serbest bırakılmış, ancak Elçiliğin yazılı protestosuna ve müfettişliğin başvurusuna rağmen, kendi hesabına öğrenim gören bir öğrenci serbest bırakılmamıştır (BCA, 30.10.0.0 / 142.13.20.3).

\section{Üniversite - Okuldaki İşleyiş}

Çeşitli ülkelere öğrenim görmek için gönderilen öğrencilerin gittikleri üniversite ve okullardaki eğitimöğretim süreçlerinde yapılan düzenlemeler öğrencilerin öğrenimlerini zaman zaman olumsuz yönde etkilemiştir. Örneğin; Vekâlet hesabına Burhanettin Kamil, yabancı dil öğrenimi için 1928 yılında doktora öğrenimine gönderilmiştir. 1933'te doktorasını bitirmesi gerekirken doktora tez danışmanının değişmesi üzerine 1935 sonuna kadar öğrenim süresi uzatılmıştır (TTKK, 1934).

1933-1934 yılında çocuk bakımı öğrenimi için Belçika'ya gönderilen ve öğrenim planlarına göre birinci yılını yabancı dil için hazırlanmak ve sonra iki yıl bu ülkede öğrenimini tamamladıktan sonra Paris'te bulunan "Ecole de Puériculture"e yerleşmeleri gereken Zekiye Ali ve Hatice Kamber Hanımlar, Belçika' daki okulun tadilatta olması ve öğrenim planlarına göre bu ülkede başka bir okul olmaması nedeniyle Paris'e nakledilmişlerdir (TTKK, 1935).

1933-1934 ders y1lı başında Ev idaresi öğrenimi için Viyana'ya gönderilen Mücedded Akif'in okulun bulunduğu yerin havası ile uyuşmaması, okul hakkındaki şikayetlerinin doğruluğuna inanılması ve bu okulun bina, araç ve öğretim unsurları itibariyle iyi bir vaziyette olmaması nedenleriyle, 1935 yılından sonra Berlin'de Letteveren okuluna yatılı olarak nakline karar verilmiştir (TTKK, 1935).

Gönderilen ülkenin eğitim sisteminde yaptığı düzenlemeler, öğrencilerin öğrenim sürelerini doğrudan etkilemiş ve bu durum öğrenci müfettişlerinin düzenli kontrolleri sonucunda rapor edilmiş ve yapılan değişikliklere göre yeni stratejiler ve öğrenim planları düzenlenmiştir. Hatta gelişmeleri yakından takip etmelerinin sonucu, bulunulan ülkenin ileride yapacağı düzenlemelere dönük olarak da eylem planları belirlenmiştir. Örneğin; Berlin'de bulunan Öğrenci Müfettişi Nihat Adil Erkman'ın 30.10.1940 tarihli raporuna göre, Almanya'da senede iki sömestr öğrenim süresi varken, üç sömestre çıkmasının öğrenim süresini uzatacağı belirtilmiş ve bu durumdan etkilenen öğrencilerin listesi düzenlenmiştir. Ancak ilkbaharda, trimester usulünden, sömestr usulüne geçiş yapılacağı, günün gazetelerinden resmi bir açıklama yapıldığı ve öğrencilerin yine eski öğrenim planlarındaki sürelerine göre bitireceği belirtilmiştir. Ayrıca trimester uygulamasıyla öğrencilerin tatil süreleri kısa olacağından ve polisten vize almanın uzun sürmesinin sonucu, yaz döneminde ailelerinin yanına giden öğrenciler için durumun zorlaştığı ve ancak 6 öğrencinin Türkiye'ye gidebildiği (BCA,30.10.0.0 / 142.14.12) belirtilmiştir.

Yukarıdaki durumlarda olduğu gibi, elçiler ve öğrenci müfettişlerinden gelen raporlarda ve yazışmalarda, gönderilen ülkelerdeki eğitim sisteminde ve okullardaki her türlü değişiklik yakından takip edilmiş ve gerekli tedbirler alınmaya çalışılmıştır. Öğrenci müfettişleri öğrencilerin kişisel sorunlarını yakından takip ettikleri gibi, öğrenim planı ve okul işleyişini de düzenli olarak takip etmişlerdir. Ancak sınırlı sayıda müfettiş ile bu kontrollerin zamanında ve yeteri kadar yapılamadığı söylenebilir.

\section{Öğrenim Planları ve Süreleri}

Çeşitli ülkelere belirli bir öğrenim planı çerçevesinde gönderilen öğrenciler için bu planların zaman zaman sorunlara yol açtığı söylenebilir. Diğer bir ifadeyle planlanan sürenin kısalı̆̆ı, planlanan sertifikalardan, derslerden farklı sertifika ve derslerin alınması gibi durumların öğrencilerin öğrenimlerini etkilediği görülmektedir. Örneğin; 1924-1925 y1lında Namık Bey Hükümet hesabına Budapeşte'ye Türkoloji öğrenimi için gönderilmiştir; ancak 1928 yılında öğrenim planına göre öğrenim süresi içerisinde öğrenimini tamamlayamadığı için memlekete dönüşü kararlaştırılmış ve kendi hesabına öğrenimine devam etmesi durumunda bir sene daha izin verilmiştir. Daha sonra öğrenim gördüğü okul tarafından öğrenimine altı ay daha ihtiyaç duyulduğunun bildirilmesi sonucunda tahsisatı Vekâletçe karşılanmak üzere bu izin verilmiştir (TTKK,1929).

1929-1930 ders yılında Vekâlet hesabına hukuk öğrenimi için Rüştü Nuri Bey, Fransa'ya gönderilmiştir. Fransa'da Siyasi İlimler Akademisini bitirmesi ve iktisat diploması alması üzerine öğrenimi yeterli görülerek geri çağrılmış; ancak öğrenim planına göre amme hukuku diplomasını alması ve hukuk doktorasını yapması gerektiğinden 1935 Kasım ayı sonuna kadar Fransa'ya tekrar gönderilmiştir (TTKK, 1935).

1930 yılında Kütahya valiliği hesabına Ömer Necati, Budapeşte’ye Su Mühendisliği öğrenimine üç seneliğine gönderilmiştir; ancak öğrenim süresi dört yıl olduğu için daha üçüncü sınıfta süresi bitmiş ve 
İl Genel Meclisi'nin süre uzatılmasını kabul etmemesi üzerine öğrenci, Nafia Vekaleti hesabına alınmıştır (TTKK, 1933).

İktisat Vekâleti hesabına Budapeşte'de doktora öğrenimi gören Mehmet Naci, öğrenim planı çerçevesinde öğrenimini tamamlayamadığı için tahsisatı 1930 Haziran ayında kesilmesine karşın, müfettişliğe başvurusu sonucunda haziran ve temmuz aylıkları harcırah ve sınav masrafları olarak kendisine verilmiştir. Doktora tezini bastırmak ve doktora masrafları için 1280 pengö ile 150 lira daha talep etmiş ve isteği başmüfettiş Cevat Bey tarafından Vekâlete bildirilmesine karşın, Maarif Vekilliği 27.07.1931 tarihli yazısında, tasarruf nedeniyle bütçe imkansızlı̆g y yüzünden bu isteğin karşılayamayacağını ve mümkün olan fedakarlık yapılarak kendisine ikinci defa dönüş harcırahı gönderildiğini bildirmiştir (BCA, 180.09.0.0 / 44.226.1).

Doktora yapmak üzere Fransa Lyon'da Zoologie öğrenimine gönderilen Suat Nigar'ın öğrenim süresi, Lyon Üniversitesi Fen Fakültesi Zoologie Profesörü M.C.Vaney'in mektubu ile Paris öğrenci müfettişliğinin mektupları sonucu bir yıl daha uzatılmıştır (TTKK, 1931).

Vekâlet bir öğrenim planı ile öğrencileri yurt dışına göndermesine karşın, öğrencilerin öğrenim planlarındaki ders/dersleri almayıp bir üst kura, üniversiteye geçmelerine de sıcak bakmıştır. Örneğin; 1932-1933 ders yılında Vekâlet hesabına, matematik ve fizik öğrenimi görmek üzere Fransa'ya gönderilen ve öğrenim planlarına göre üç sene içinde sırası ile "Mathématiques Elémentaires", "Mathématiques spéciales A" ve "Mathématiques spéciales B" sınıflarını takip ettikten sonra üniversiteye girmeleri gerekenler bulunmaktadır. Vekâlet, bu durumda olanlardan isteyenlerin Mathématiques spéciales B" sınıfında bir sene bırakılmadan, öğretmenlerinin üniversiteye girebileceğine dair bir rapor vermesi sonucunda bu taleplerinin karşılanabileceğini belirtmiştir (TTKK, 1934).

\section{Maddi Konularda Karșılașılan Sorunlar}

Öğrencilerin, öğrenim için gönderilen paralarını zamanında alamamaları başlı başına büyük bir sorundur. Bu sorun Avrupa'ya öğrenci gönderilmesi sürecinde kaçınılmaz olarak yaşanan bir sorundur. Hariciye Vekaleti'nin 27.1.1925 tarihli Maarif Vekâleti'ne gönderdiği Berlin Büyükelçiliği'nin raporuna göre, İtalya'ya gönderilmiş öğrencilerin tahsisatının devretmesi yüzünden zor durumda oldukları, öğrencilerin derslerini ciddi bir surette takip edemeyeceği ve bu şartlarda yetişen öğrenciden ise hükümet ve milletçe ihtiyaç olunan faydanın gerçekleşemeyeceği ve öğrencinin parasızlık yüzünden, türlü sefalet ve zaruret içinde ezilip kaldığı belirtilmektedir. Bu sorunun yanı sıra aynı ülkeye gönderilmiş öğrencilerin birbirinden farklı öğrenim ücreti alıyor olmaları da başka bir sorun olarak ortaya çıkmaktadır. Raporda Ticaret Vekâleti öğrencisi 80 lira alırken, Nafia Vekâleti'nden 60-80 lira arası ücret alanlar olduğu, aynı durumda olan öğrencilerin ücret farklılı̆̆ının kaldırılması gerektiği belirtilmektedir (BCA, 180.09.0.0 / 34.181.1).

Vekâlet dışındaki kurumlardan, valilikler ve belediyelerin öğrenim için yeteri kadar bütçe ayırmaması sonucunda, öğrenciler zor duruma düşmüşler ve durumlarına göre Vekâlet hesabına alınmışlardır. Örneğin;1928 yılında Mehmet Arslan, Galatasaray Lisesi'nden mezun olup, Kars Valiliği adına ve hesabına Paris'te "Ecole des Travaux Puplics"”te öğrenime gönderilmiştir. Çok çalışkan ve kıymetli bir genç olarak tanımlanması ve valilik tarafından yeterli derecede tahsisat gönderilmeyeceği düşüncesiyle Vekâlet hesabına alınmıştır (TTKK, 1930).

1930-1931 tarihinde Bolu Vilayeti hesabına Ömer Necmettin, Macaristan’a Maden Mühendisliği öğrenimi için gönderilmiştir. 1934 yılında bütçede karşıllı̆ 1 olmadığ 1 için tahsisatı kesilmiş ve öğreniminin son kademesindeyken İktisat Vekâleti hesabına alınmıştır (TTKK, 1934).

Yukarıdaki sorunlar çerçevesinde ortaya çıkan durumlara yönelik olarak ise, Berlin Büyükelçiliği 1925 tarihli raporunda "öğrencinin adreslerindeki tahakkuk dolayısıyla genellikle paralarını almadığı ve paranın iade olduğu" tespiti yapılır. Bu tür sorunlara çözüm olarak Elçilik "her daire öğrencisine ait öğrenim ücretini öğrenci müfettişliğinin adresine göndermelidir” (BCA, 180.09.0.0 / 34.181.1) biçiminde bir öneri geliştirse de, elçiliğin bu önerisi gerçekleşememiştir.

\section{İç Faktörler}

\section{Yaş ve Cinsiyet Farklılığı}

Gerek Meşrutiyet dönemi gazete ve dergilerinde gerekse Cumhuriyetin erken döneminde müfettiş raporlarına yansıyan, yurt dışına gönderilen öğrencilerin seçimi meselesinde asıl konu seçilen öğrencilerin belirli bir olgunlukta olup olmamalarıdır. Elçiliklerden ve müfettişlerden gelen raporlarda 
da yaş sorunu vurgusu öne çıkmaktadır. Örneğin; Berlin Büyükelçiliği'’nin 1925 tarihli raporunda küçük yaşta öğrenci gönderilmesinin doğru olmadığı, milli terbiyesini almış öğrencilerin gönderilmesinin doğru olduğu belirtilmiştir. Ayrıca rapor, yurt dışına öğrenci gönderilmeden önce İstanbul' da 6 ay veya 1 sene süreyle hazırlık kursları almasının gerektiğini, burada Fransızca ve İngilizce dillerinin takviyesi ve Avrupa görgü kurallarına dair derslerin verilmesini, özellikle Anadolu'dan gelen öğrencilerin İstanbul'da büyük şehir hayatına uyum sağlamış olarak, Avrupa'ya gönderilmesinin onların başarılarını arttırmada önemli olduğunu söylemektedir (BCA, 180.09.0.0 / 34.181.1).

1926 yılında Fransa'da bulunan müfettiş Kemal Za'im Bey'in öğrencilerle ilgili raporunda ise gerek fen gerek edebiyat fakültelerine devam eden öğrencilerden en sıkıntılı vaziyette bulunanların darülfünun mezunları ve öğretmenlik yapmış olanların oluşturduğu belirtilmektedir. Raporda Fransa' da düzenli bir öğrenimde bulunabilmek için esaslıca hazırlık devresine ihtiyaç olduğu ve bunun için de öğrenime liseye belirli bir olgunluktan sonra gelip yurt dışındaki liselere devam etmeleri gerektiği belirtilmektedir (MVM, 1926).

1927 yılında yayınlanan “Ecnebi Memleketlere Gönderilecek Talebe Talimatnamesi”ne bu konuda yaşanan sorunlar göz önüne alınarak Avrupa meslek okullarına, ortaokul öğrenimini bitirmiş olanların ve Avrupa öğretmen okullarına ise lise veya ilk öğretmen okulunu bitirmiş olan gençler gönderilmesi kuralı konulsa da, öğrencinin olgunluğu konusu sorun olmaya devam etmiştir. Aynı tarihte yayımlanan bir başka yazıda, meslek öğretmeni yetiştirmek üzere Avrupa'ya gönderilecek öğrencilerden erkeklerin lise mezunu, kızlardan biçki ve dikiş için gideceklerin ortaokul mezunu ve yaşı on altıyı geçmemesi şartı (Maarif Vekâleti Tebliğler Mecmuası, 1927) bulunması kararı bu talimatnamenin somut göstergesidir. Ancak, Kemal Za'im Bey'in ortaya koyduğu belirli bir olgunluktaki öğrencilerin, öncelikle gittikleri ülkenin liselerine devam etmeleri gerektiği sorunu, 1929 y1lında kabul edilen 1416 sayılı kanunla, lise ve üzeri okul mezunlarının gönderilmesiyle kısmen giderilmiş olsa da, 1930 tarihinde düzenlenen müfettişler toplantısında "öğrencilerin gidecekleri ülkelerdeki liselerde iki yıl kaldıktan sonra darülfünunlara geçmeleri” (MVM, 1930) gerektiği talepleriyle devam ettiği söylenebilir. Bu öneri olgunluk sorununa bir çözüm adımı olarak değerlendirilebilir. Her ne kadar 1416 sayılı Kanun'la lise ve üzeri ögrenime sahip öğrencilerin gideceği kararlaştırılsa da,1938 yılında gazetede verilen bir ilana göre, ortaokul mezunlarının da öğrenim için yurt dışına gönderilebildiği görülmektedir. Örneğin, Denizbank makine ve inşaiye mühendisi yetiştirmek üzere Avrupa'ya göndereceği öğrencilerin esaslı bir öğrenim ve staja tabi tutulabilmesi için ortaokul mezunlarının dahi başvurabileceğini duyurmuştur (Cumhuriyet, 1938).

Öğrencilerin yaşı ve olgunluğu sorunu Berlin Büyük Elçiliği’nin 1940 tarihli raporunda da görülmektedir (BCA, 30.10.0.0 / 142.14.8). Buna göre, Berlin'de bir Öğrenci Cemiyeti kurdurulmuş, kulüp binasında öğrencilere oturacak yer, radyo, görüşme salonu, gazete ve ekonomik olarak zor şartlara rağmen çay içme olanağı dahi sağlanmıştır. Elçilik, öğrenciler için tesis etmiş olduğu bu sosyal mekana rağmen öğrencilerin şehrin seçkin kahvelerinde genç kızlarla oturanlarının, sinema ve barlarda dolaşanlarının epeyce olduğunu belirtmektedir. Bunların başlıca nedenleri olarak, öğrencilerin iyiyi kötüyü fark edecek yaşta olmamalarını, çok genç olmalarını, Almanya'ya niçin geldiklerinin fark edecek öğrenim ve olgunluk derecesinde olmamalarını ve ellerine fazla para geçmekte olmasını göstermektedir. Raporda gelen öğrencinin 30 yaşından aşağı olmaması gerektiği bildirilmektedir. Hatta çok genç gelen, senelerce Almanya'da oturan ve büsbütün Avrupa'da yetişmiş olanlardan memleketin şimdiye kadar, müstesnalar hariç, fayda görmediği belirtilmektedir. Her ne kadar "Batı ülkelerine lise ve yüksekokullar mezunları arasından seçim yapılmıştır" denilse de böyle bir uygulamanın, bazı özel şirket ve kuruluşların yurt dışına öğrenci gönderilmesi sınavlarında ortaokul mezunlarından da öğrenci alması nedeniyle kısmen uygulandığı söylenebilir.

\section{Dil Problemleri}

Çeşitli ülkelere öğrenim görmek için gönderilen öğrencilerin, gittikleri ülkenin eğitim dilini bilme düzeyleri onların okul başarılarını etkilemiştir. Bu durum çeşitli toplantılarda da görüşülmüş ve yeni düzenlemeler yürürlüğe konulmuştur.

1929-1930 yılı teftiş işlerinin sonucunda gerçekleştirilen müfettişler toplantısında Avrupa'daki öğrencilerin çoğunlukla görevlerine dikkat ettikleri, öğrencilerden en çok başarılı olanların matematik ve fen öğrencileri, en zorlananların ise öğrenim gördükleri alanın iyi bir lisana ihtiyaç duyması nedeniyle tarih ve edebiyat öğrencileri olduğu belirtilmektedir. Ayrıca özellikle dil öğrenimine gönderileceklerin öğrenim göreceği dili bilmesi ve bu surette o dili öğrenmeye olan yeteneğinin görülmesi gerektiği 
vurgulanmaktadır (MVM, 1930). Dil problemiyle ilgili olarak 1929 yılındaki bir yazıda, Almanya'da üniversitelerin öğrenci kabul şartlarının değiştiği ve lisan öğrenmeye ayrılan iki sömestr süresinin yeterli olmadığı belirtilmektedir. Alman öğrencilerin bile asgarî doktora süresince veremediği imtihanları, giden öğrencilerin en kısa müddet zarfında vermekle mükellef tutulmasının imkansızlığı anlaşılarak, bu durumun çözümüne yönelik olarak yeni bir öğrenim planı oluşturulmuştur (TTKK, 1929).

Bir taraftan yapılan teftişler sonucunda sorunlar ve çözümleri ortaya konulmaya çalışılsa da dil sorunu öğrencilerin karşılaştıkları ve başarısız oldukları önemli bir konudur. Örneğin; Nazım Sami, Fransa’ya Ticaret öğrenimi görmek üzere gönderilmiştir. Bulunduğu okul müdürlüğünün Paris Mıntıka Müfettişliğine gönderdiği mektupta bilgisinin yetersiz ve Fransızcasının da zayıf olduğunun bildirilmesi sonucunda müfettişliğin bu doğrultudaki yazısı üzerine geri çağrılmasına karar verilmiştir (TTKK, 1932).

1932 yılında Bina doğramacılığı ve sınaî resim öğrenimi için Prag’a üç öğrenci gönderilmiştir. Talim ve Terbiye Kurulu'nda Elçilikten ve Berlin Öğrenci Müfettişliğinden gelen yazılar uyarınca bu üç öğrencinin de Çekçe öğrenmek zorunda oldukları, Çekçeyi öğrenmenin zor olduğu, bu dilde yeterince meslekî yayın olmadığ 1 ve öğrencilerin bu sahada bilgilerini artırmak için Almanya'ya nakil edilmeleri görüşülen sorunlardan birisidir. Kuruldan iki üyenin (A.Haydar Bey ve M. Reşat Bey) Prag'da kalma isteklerine karşın çoğunluk kararla öğrencilerin Almanya'ya nakillerine karar verilmiştir (TTKK, 1933).

\section{Okula ve Çevreye Yönelik Tutumlar}

Öğrencilerin gittikleri ülkelerin sosyo-kültürel yaşamına uyum sağlamalarında ve başarılı olmalarında kuşkusuz tutumları önemli bir rol oynamaktadır. Bazı öğrencilerin tutumları gidilen ülkeye yönelik olumsuz biçimdeyken bazı öğrencilerde ise okula ve çevreye yönelik olarak olumsuz biçimde gelişmektedir. Her ne kadar kökeninde maddi sorunlar varmış gibi gözükse de öğrencinin çevreye yönelik tutum ve davranışlarının sonucu bazı olumsuz olaylar gerçekleşmiştir. Örneğin, öğrencilerin bir kısmı ev sahiplerine ay sonunda kira ödemeleri gerekirken, ay sonunda geceleyin evi boşaltarak başka bir eve taşınan ve her ay bunu yapan öğrenciler bulunmaktadır. Bu durumda olan öğrencilerin çoğu mahkemelik olmuştur (BCA, 30.10. 0.0 / 141.9.14).

Gidilen ülkeye yönelik tutuma, 1930 yılında yapılan müfettişler toplantısında belirtilen, öğrencilerin küçük milletlerin lisanını lâyıkıyla öğrenmeye ilgi ve istek duymadıkları için Macaristan ve Çekoslovakya'ya Tarih ve filoloji müstesna olmak üzere gönderilmemesi isteği örnek olarak verilebilir (MVM, 1930).

Bazı öğrenciler ise okula yönelik olumsuz bir tutum geliştirmişler ve sorumluluklarını yerine getirmemişlerdir. Örneğin; Bahattin Efendi, Bruxelles'e makine öğrenimi için gönderilmiştir. Müfettiş Salih Zeki Bey'in kendisine yaptığı uyarılara rağmen hayatını düzenleme ve okula devam konusunda sorumluluklarını yerine getirmediğinden, kendisinden bir fayda beklenmediği düşüncesiyle geri çağrılmasına karar verilmiştir (TTKK, 1930). Benzer biçimde askerî fabrikalar umum müdürlüğü hesabına Almanya'da öğrenimde bulunan Suavi Naili'nin, okula yönelik olumsuz tutumu sonucunda 152 saatlik devamsızlığı olmuştur ve Almanya'da daha fazla kalmasında bir fayda görülmeyerek geri çağrılması kararlaştırılmıştır (TTKK, 1931).

\section{Derslerden Başarısızlık}

Yurt dışına öğrenim için gönderilen öğrencilerin öğrenim planlarında yer alan derslerden başarılı olamamaları, öğrenim planlarında ve sürecin işleyişinde aksaklıklar yaşanmasına yol açmıştır. 1925 tarihli Berlin Büyükelçiliği'nin raporuna göre İtalya'da bulunan öğrencinin, müfettişin kontrolünde tutulmasının önemli olduğu belirtmiştir. Ayrıca derslerine devam etmeyerek, başarılı olamayan öğrencinin derhal geri çağrılması ve bu hususta alınacak kesin bir kararın öğrenci üzerinde etkisini göstereceği, bir iki öğrencinin memlekete iadesinin tüm öğrenciler için bir ders olacağı savunulmaktadır. Bunların memuriyete alınabilmesi için her dairenin kendi öğrencisine her üç ayda bir imtihan belgelerini öğrenci müfettişliğine ibraza mecbur tutulması gerektiğinin önemi belirtilmektedir (BCA, 180.09.0.0 / 34.181.1).

1925 yılında Nihat Ali Bey, İktisat Vekâleti hesabına Fransa'ya Siyasal Bilimler öğrenimine gönderilmiştir; ancak 1931 yılı itibariyle diploma sınavında başarısız olmuş ve öğrenimini tamamlayamadan geri çağrılmıştır (TTKK, 1931). Benzer biçimde 1925-1926 yılında kendi hesabına Belçika'da Anvers'te Ticaret Yüksekokulu'nda bulunan Süleyman Faik, hakkındaki okul idaresinin 
mutalaası ve Yüksek Öğrenim Umum Müdürlüğü’nün tezkeresi sonucunda öğrenime devamında bir fayda olmadığı anlaşıldığından geri çağrılmıştır (TTKK, 1928).

1927 y1lında Server Hanım, Vekâlet hesabına tarih öğrenimi görmek için Fransa'ya gönderilmiştir. Darülfünun mezunu olmasına karşın, Fransa'da Aix Lisesi'ne ve sonra Üniversite'sine girmiştir. Ancak 1930 yılı itibariyle bir sertifika bile alamadığı için, geri çağrılıp, öğretmenlik görevi verilmesi kararlaștırılmıștır (TTKK, 1930).

1928 y1lında Sadiye Abdurrahman Hanım, Vekâlet hesabına felsefe lisansı yapmak üzere Bordeaux Üniversitesi'ne gönderilmiştir. Kendisi üçüncü sertifikasını almak üzere girdiği umumî felsefe ve mantık imtihanında üç defa üst üste başarılı olamamıştır. Üçüncü sertifikasını aldığı takdirde dördüncü sertifika için 1933 Temmuz ayına kadar müsaade edilmesine, başarılı olamadığı takdirde geri çağrılmasına karar verilmiştir (TTKK, 1932).

1928 yılında Hamdi Ragıp (Atademir) ve Nurettin Sitkı Efendiler, Felsefe ve Edebiyat öğrenimi için Fransa'ya gönderilmişlerdir; ancak 1931 yılına kadar hiçbir sertifika alamadıkları için ve o yıl yapılacak sınavlarda da bir başarı elde edemezlerse geri çağrılmalarına karar verilmiştir (TTKK, 1931).

1928 yılında Fuat Cahit, Hüseyin Sadi, Enver Ziya (Karal) ve Derviş İbrahim Efendiler, Tarih-Coğrafya öğrenimi için Fransa'ya gönderilmişlerdir. 1931 yılına kadar hiçbir sertifika alamadıkları için ve o yıl yapılacak sınavlarda da bir başarı elde edemezlerse geri çağrılmalarına karar verilmiştir (TTKK, 1931). 1929 yılında Hüseyin Remzi Bey Vekâlet hesabına matematik öğrenimi için gönderilmiştir. Remzi Bey hem lise hem de üniversite eğitimine gönderilmiştir. İlk y1l lisede lisan öğrenmekle geçirmiştir. Lise ve üniversite öğrenimlerinde alması gereken sertifikaların hiç birisini alamadığından ve 1934 yılında öğrenim süresi sona ereceğinden öğrenime devamında bir fayda beklenmediği için geri çağrılmıştır (TTKK, 1934).

1929 y1lında İktisat Vekâleti namına Hayri Aziz, Nancy şehrinde "Ecole Nationale des Eaux et des Forest'de Ormancılık öğrenimi için gönderilmiştir. Ancak birinci sınıfta kalması ve Müfettiş S. Zeki Bey'in hakkında hazırladığı matematik bilgisindeki yetersizlikler, okulu bitiremeyeceğine dair raporu sonucunda, Fransa'da öğrenime devamında bir fayda olmayacağı düşünülerek geri çağrılmıştır (TTKK, 1931).

Fuat Efendi 1930/31 yılında Marsilya'da Ticaret öğrenimindeyken birinci sınıfında kalmış ve bu nedenle tahsisatı kesilmiştir; ancak bir sene kendi hesabına öğrenimine devam ederek sınıfını geçtiğinde tekrar Vekâlet hesabına alınması kararlaştırılmıştır (TTKK, 1931).

Derslerinde başarısız olmamasına karşın, mezuniyet sınavında başarılı olamayıp geri çağrılanlar da bulunmaktadır. Nihat Ali 1925 yılında, İktisat Vekâleti hesabına Fransa'ya Siyasal Bilimler öğrenimine gönderilmiştir; ancak 1931 yılı itibariyle diploma sınavında başarısız olmuş ve geri çağrılmıştır (TTKK, 1931).

Vekâlet, öğrenim planında belirtilen tarihlerde sertifika alamayanları geri çağırdığı gibi bazılarının da kendi hesaplarına öğrenimlerine devam etmelerine izin vermiş ve hatta tekrar Vekâlet hesabına alınmak isteyenlerin bu isteklerini kabul etmiştir. Örneğin; Hüseyin Sadi, 1928 yılında Vekâlet hesabına Tarih ve Coğrafya öğrenimi görmek üzere Fransa'ya gönderilmiştir. 1931 Ekim ayına kadar sertifika alamaması sonucunda tahsisatı kesilmiş ve 1934 yılına kadar kendi hesabına öğrenimine devam ederek "Esthétique" ve "Géographie" sertifikalarını almıştır. 1935 Kasım ayına kadar tahsisat verildiği takdirde lisansını tamamlayacağını beyan etmesi üzerine Vekâlet, kendisinin aldığı bu iki sertifikadan başka "Géographie Physique" ve"Histoire Modern et Contemporaine" sertifikalarını alarak lisansınıtamamlaması yönünde karar almıştır (TTKK, 1934).

\section{Sağlık Sorunları}

Her ne kadar öğrencilerin gönderilme koşulları ararında săglık raporu olsa da öğrenciler hastalandıklarında, maddi koşulları sonucunda zor günler yaşamışlardır. Berlin Büyükelçiliği’nin 29 Aralık 1926 tarihli raporunda, dişi ağrıyan bir öğrenci yeteri kadar parası olmadığı için doktora gidememiş ve rahatsızlı̆̆ ölme noktasına gelmiştir. Elçilik tarafindan öğrenci 400 mark gibi bir bedel ödenerek ameliyat edilmek durumunda kalınmıştır. Ayrıca birçok öğrencinin ağır rahatsızlıklarını kendi ikamet ettiği evlerinde geçirdiği belirtilmektedir (BCA, 30.10.0.0 / 141.9.14). Dolayısıyla öğrencilerin ciddi sağlık sorunlarının sonucunda derslerinde sıkıntılar yaşadığı söylenebilir. Bu sıkıntıları daha şiddetli biçimde yaşayarak, öğrenim süresini planlanan sürede sağlık nedenlerinden dolayı bitiremeyenler de bulunmaktadır ve bu durumda olanların başarı durumlarına göre öğrenimlerine devam edip etmeyeceklerine dair kararlar alınmıştır. Örneğin; Maarif Vekâleti hesabına Paris’te felsefe 
öğrenimi görmek üzere 1928 yılında gönderilen Tevfik Bey, 1932 yılında geçirdiği apandisit ameliyatı sonucu sertifika imtihanına girememiş ve öğrenim süresi 1933 Aralık ayı sonuna kadar uzatılmışıır (TTKK, 1933).

1928 yılında Vekâlet hesabına matematik öğrenimi görmek üzere Lütfi İsmail Bey, Fransa'ya gönderilmiştir. Hastalığından dolayı kendisine bir yıl izin verilmiş ve öğrenim süresinin sonu olan 1934 yılı sonuna kadar alması gereken üç sertifikadan ikisini alabilmiş ve lisansını bitirememiştir. Paris mıntıkası öğrenci müfettişliği tarafından öğrenim süresinin uzatılması veya geri çağrılarak Yüksek Öğretmen Okuluna alınması ve son sertifikasını Türkiye'de alması bildirilmiştir. Ancak Vekâlet tarafından Lütfi İsmail Bey'in son sertifikasını alarak lisansını bitirmek üzere kendi hesabına okumak istediği takdirde bir yıl daha Fransa' da kalmasına izin verilmiş ve bu süre içinde de lisansını alamadığı takdirde geri çağrılması ve hakkında takibat yapılması kararlaştırılmıştır (TTKK, 1935).

Sağlık sorunları nedeniyle Avrupa'ya öğrenim için gitmek üzere açılan sınavlarda başarılı olsalar bile gidemeyenler, gitmeleri ertelenenler de bulunmaktadır. 1931 yılında Askerî Fabrikalar Genel Müdürlüğü hesabına Avrupa'ya gönderilecek öğrenci sınavında başarılı olan Salâhattin Beyin, rahatsızlığ 1 nedeniyle Cerrahpaşa hastanesinin vermiş olduğu rapor sonucunda, "vücudunu kuvvetlendirinceye kadar" Avrupa'ya gönderilmesi ertelenmiştir (TTKK, 1931).

Yurt dışında eğitimini sürdüren öğrencilerin bir kısmı rahatsızlığı nedeniyle öğrenimini yarıda kesme durumunda kalmış ya da bu karar Vekâlet tarafından kişinin aldığı eğitim yeterli görülerek, öğrenci geri çağrılmıştır. Örneğin, Maarif Vekâleti hesabına Lyon'da matematik öğrenimi gören Gülfeza Mehmet Hanım, çeşitli sertifikalar alarak lisansını yapmış ve ilave olarak da Genel Fizik sertifikası için öğrenimine devam etmiş ve öğrenimine başlayacağı sırada, yaz tatilinde geçirdiği boğaz ameliyatının kendisini zayıf düşürmesi sonucunda sertifika imtihana girememiş ve öğrenimi yeterli görülerek geri çağrılmıştır (TTKK, 1933).

Lûtfü Efendi, Vekâlet hesabına Fransa'da Montpeiller Lisesi'nde öğrenime gönderilmiştir; ancak ciğerlerinden rahatsızlanması sonucu İstanbul Cerrahpaşa hastanesinde tedavi görmüş ve altı ay daha dinlenmeye ihtiyacı olması sonucunda, bir sene içinde iyileşmesi durumunda müktesap hakk1 saklı kalmak şartı ile izinli kabul edilmiş ve bu sürede kendisine herhangi bir tahsisat verilmemesi kararlaştırılmıştır (TTKK, 1931).

Vekâlet hesabına matematiköğrenimi için 1929 senesinde Almanya'ya gönderilen Mehmet Şükrü Efendi, öğrenim planına göre 1934 yaz sömestresinde öğrenimini bitirmesi gerekirken hastalanarak uzun süre hastanede yatmış, bu esnada Yahudi olan profesörü Alman hükümeti tarafından işten çıkarılmış ve bu sebeple eski profesörünün yanına gönderilmiş olmasından dolayı imtihanından geciktiği için, öğrenim süresi 1935 yaz dönemine kadar uzatılmıştır (TTKK, 1934).

1928 y1lında Tarih-Coğrafya öğrenimi için Almanya'ya gönderilen Edirne Lisesi mezunlarından Süleyman Sami Beyin, sağlık durumu kötüleşmeye başlayınca, hem doktor kontrolleri hem de Vekâlet'in emri üzerine orada bir heyet tarafindan yapılan muayene sonucunda öğrenime devam edemeyeceği anlaşılarak, Türkiye'ye dönmüştür. Ancak maaşı düzenli olarak Disconto-Gesellschaft bankasına gönderilmiş ve öğrenime devam edemeyecekse, boş yere maaş tahakkuk ettirilmemesi yönünde Müfettiş İzzet Bey, Vekâlete 02.11.1929 tarihli bir yazı göndermiştir (BCA,180.09.0.0 / 43.222.1).

Öyle ki yurt dışına öğrenimine gidip, yaşamını kaybeden öğrenciler de bulunmaktadır. Örneğin, 1924 yılında İstanbul Sanayi Nefise Mektebi mezunu Belkıs Hanım, Resim öğrenimi için Almanya, Berlin'e gönderilmiştir, ancak 1925'te vefat etmesi sonucu öğrenimini tamamlayamamıştır (BCA, 180.09.0.0 / 34.181.1).

\section{Evlilik}

Yurt dışına öğrenim için gönderilen öğrencilerin, gittikleri ülkelerde veya sömestr dönemlerinde Türkiye'ye dönüşlerinde evlenmeleri öğrenim planlarını aksattığı gibi, yabancı bir kadınla evlenmeleri, onların öğrenim parasının kesilmesine ve öğrenciliğinin son bulmasına yol açmıştır. Örneğin; Nasıh Bey, Darülfünun Tıp Fakültesi adına Belçika'ya tıp öğrenimine gönderilmiştir. Ancak Brüksel Maslahatgüzarlığının resmi yazısı ve belgesi ile Avrupa öğrenci müfettişi Tevfik Bey'in yazısıyla Belçika'da yabancı bir kadınla evlendiği anlaşıldığından Memurin Kanununun 4. maddesi uyarınca devlet hizmetinde istihdamına imkan kalmadığı için tahsisatının hemen kesilmesi ve kendisinden tazminat alınmak üzere hukuki sürecin başlatılması istenilmiş̧ir (TTKK, 1931). 


\begin{abstract}
Ailevi Nedenler
Kendi hesabına giden öğrencilerden bir kısmı ailesinin maddi zorlukları sonucunda öğrenimlerine devam etme sorunu karşısında vekâletlere başvurarak, kendilerinin 1416 sayılı kanun kapsamına alınma isteklerini bildirmişlerdir. Dolayısıyla öğrencilerin ailevi nedenlerden dolayı içine düştükleri durum bu başlık dahilinde değerlendirilebilir. Örneğin, 1925 yazında kendi hesabına Almanya'ya makine mühendisliği öğrenimine giden Ziya Saffet Bey, 1925-1926 kış döneminde İktisat Vekâleti hesabına alınmıştır. 1930 yılında öğrenimini bitiremediği için tahsisatı kesilerek geri çağrılmasına karşın, annesinin yardımıyla öğrenimine devam etmiş ve 1931 yılında inşaat mühendisliğini bitirerek yurda dönmüştür (BCA, 180.09.0.0 / 44.228.1).

Kendi hesaplarına yurt dışına öğrenime gidip mali vaziyetlerinin uygun olmaması nedeniyle üç öğrenci Cenan Zihni, Vedide Baha ve Güzin İhsan Hanımlar hükümet hesabına alınmışlardır ve bu öğrencilerden Vedide Baha Hanım daha sonra İstanbul pedagoji kürsüsünün gelişiminde önemli katkılarda bulunmuştur (TTKK, 1929).

Maarif Vekâletine başvurarak kendilerinin 1416 sayılı yasa kapsamına alınması isteyenlerin bir kısmı kabul edilirken bir kısmı da kabul edilememiştir. Örneğin CHP Genel Sekreteri Recep Bey (Peker)'e, Paris'te mühendislik öğrenimi gören Şeref Bey'in öğreniminin son zamanlarında babasının düştüğü ekonomik kriz üzerine devlet hesabına alınması için yazdığı mektuba Nafia Vekilliği, yeniden öğrenci alınması için Maarif Vekâleti bütçesinin uygun olmadığı ve ecnebî memleketlerde bulunan 12 öğrenciye bile kifayet etmeyeceği gerekçeleriyle olumsuz yanıt vermiştir (BCA, 490.01.0.0 / 1190.170.2).
\end{abstract}

\title{
SONUÇ
}

Cumhuriyetin erken dönemi eğitim politikalarının ayrıntılı, planlı, ilkeli, yasa ve yönetmeliklere dayalı, ülkenin çıkarları doğrultusunda hazırlandığı söylenebilir. Ancak bu politikalardan biri olan yurt dışına öğrenci gönderilmesi politikasında 1929 yılına kadar istenilen verimin elde edilemediği görülmektedir. Kuşkusuz bunda yurt dışı gibi çok yönlü ve karmaşık olan bir sürecin, kontrol edilebilirliğinde yaşanan sıkıntıların belirleyici olduğu yadsınamaz bir gerçekliktir. Ülkedeki sınırlı sayıdaki müfettişlerle yurt dışındaki öğrencilerin denetlenmesi işlerinde de sorunlar yaşanmasının kaçınılmaz olduğu söylenebilir. Her ne kadar bu süreçte aksaklıklar ve sorunlar yaşansa da, düzenli olarak bu süreç devam etmiş, dış politikada takip edilen "yurtta barış dünyada barış" ilkesinin ve ülkenin ihtiyaç duyduğu alanlarda yetiştirilecek uzman ve öğreticilerin daha iyi yetişmeleri için, gönderilen ülkenin ve kentin bu ihtiyacı karşılayıp karşılamayacağ 1 durumunun belirleyici olduğu söylenebilir. Ayrıca yeni kurulan Cumhuriyetin dünyayla bütünleşme, yenilikleri yakından takip etme ve kendisi için yararlı olanı elde etme çabası içerisinde olma düşüncesinin de rolü yadsınamaz.

Yurt dışına gönderilen öğrencilerin sorunları kendilerinden kaynaklanan (iç faktörler) ve kendi kontrolleri dışında (dış faktörler) gelişen bir süreç olarak iki boyutta değerlendirilebilir. Yurt dışına gönderilen öğrencilerin karşılaştıkları sorunların başında, Elçiliklerin ve müfettiş raporlarına da yansıdığı gibi, iç faktörlerden biri olan öğrencilerin belirli bir olgunluğa erişmeden küçük yaşlarda gönderilmesi sorunun geldiği söylenebilir. İkinci olarak karşılaşılan sorunlar, dil problemi yüzünden derslerden başarısızlık, okula ve çevreyle ilişkili uyum sorunlarının yaşanması sorunları gösterilebilir. Üçüncü olarak öğrencilere ödenen aylık maaşların zamanında alınamaması karşısında öğrencilerin düştüğü ekonomik sıkıntılar gösterilebilir. Bunun sonucu olarak öğrencilerin bulundukları ülkelerde borçlanmaları, kiralarını ödeyememeleri, mahkemelik olmaları, sağlık sorunlarını çözümleyememeleri gibi durumların yaşandığı söylenebilir. Bu üç durumu da içinde barındıran dördüncü sorun, öğrenim için gönderilen ülkenin sosyal, siyasal ve ekonomik koşulları gösterilebilir. Bu sorun, öğrencilerin ülkenin bu koşullarına uyum sağlamalarında önemli bir sorun olabildiği gibi, maaşlarındaki artış ve azalmaları belirleyen, öğrenimlerinin yarıda kalmasına neden olan bir özelliğe de sahiptir. Ayrıca Vekâletler dışındaki valilikler ve belediyelerin öğrenim için yeterince bütçe ayırmamaları ve Vekâletlerin birbirinden farklı öğrenim ücreti vermeleri de diğer bir sorun olarak değerlendirilebilir. Bunların yanı sıra öğrenim görülen ülkedeki hayat pahalılığı veya ucuzluğu alınan ücretlerin yıldan yıla farklılaşmasına neden olmuştur. Beşinci sorun, gönderilen üniversite ve okuldaki işleyişle birlikte öğrencilerin kendilerine sunulan okuma planlarıdır. Bu planların sağlıklı işleyiş̧i gönderilen üniversite ve okulun öğrenim süresinde hazırlık olup olmamasına, tatil dönemleri, ders geçme sistemleri ve danışman ataması gibi değişikliklere, okulun taşınması, derslerden başarısızlık ve devamsızlık gibi durumlara bağlı olmuştur. Son olarak yurt dışındaki öğrencilerin sağlık sorunları, ölüm durumu, ailevi 
sorunlar ve medeni hallerindeki değişiklikler de diğer önemli sorunlar olarak gösterilebilir. Her ne kadar yurt dişına gönderilen öğrencilerden tam teşekküllü bir hastaneden sağlık raporu istenilse de, yurt dışındayken yaşadıkları sağlık sorunları, öğrenimlerinin yarıda kesilmesine veya tamamen bırakılmasına neden olmuştur. Ayrıca özellikle kendi hesabına yurt dışına öğrenime gelen öğrencilerin çeşitli nedenler sonucunda düşmüş oldukları ekonomik sıkıntıdan kurtulmaları için Vekâletlere yaptıkları başvuruların bir kısmı kabul edilmiş, bir kısmı ise kabul edilmemiştir. Vekâlet hesabına alınanlar, asıl öğrencilerin aldıkları aylığın yarısı kadar bir aylık maaş almalarına karşın, iki öğrenci grubu da aynı yükümlülüklere tabî olmuşlardır. Ayrıca Vekâletler dışındaki valilikler ve belediyelerin öğrenim için yeterince bütçe ayırmamaları ve Vekâletlerin birbirinden farklı öğrenim ücreti vermeleri de öğrencilerin bulundukları ülkelerde "sefalet ve zaruret içinde ezilmelerine" neden olan, kendilerinden kaynaklanmayan faktörler arasında gösterilebilir.

\section{KAYNAKLAR}

Akyüz, Y.(2008). Türk Eğitim Tarihi. Ankara: PegemA Yayınc1lı.

Antel, S. C.(1926). Maarif Teşkilatı Hakkında Bir Layiha. Maarif Vekâleti Mecmuası, 1(7), s. 135-246.

Aslan, C. (2014). Erken Cumhuriyet Dönemi’nde Eğitim Bilimleri Alanında Yurt Dışına Öğrenci Gönderilmesi Olgusu (1923-1940) (Yayımlanmamış Doktora Tezi). Ankara Üniversitesi, Ankara.

Başbakanlık Cumhuriyet Arşivi.

Cumhuriyet Gazetesi, 2 Ekim 1933, 5

Cumhuriyet Gazetesi, 22 Eylül 1938, 2.

Fındıkoğlu, Z. F.(1940). Avrupa Öğrencisi Meselesi. Ülkü Dergisi15(85), s.33-40.

Fraenkel, J.,Wallen, N. \& Hyun, H. (2012). How To Design And Evaluate Research In Education. London: McGraw-Hill Higher Education.

Lundy, K. S. (2008). Historical Research, (Aut).Lisa M.Given, Encyclopedia of Qualitative Research Methods. Los Angales: Sage Publications.

Maarif Vekâleti İhsaiyat Mecmuası (1927). 2(2), 4-6.

Maarif Vekâleti Mecmuası (1926). 2(7), 55-57.

Maarif Vekâleti Mecmuası (1930). 2(19), $27-29$.

Maarif Vekâleti Tebliğler Mecmuası (1927). 2(20), 80-82.

Milli Eğitim Bakanlığı (1977). Cumhuriyet Devrinde Milli Eğitim Bakanlı̆̆ Teftiş Kurulu. İstanbul: Milli Eğitim Basımevi.

Milli Eğitim Bakanlığı Talim ve Terbiye Kurulu Kararları (1923-1940).

Ünal, U ve Birbudak, T.S.(2010). Mustafa Sâtı Bey ve Eğitime Dair Lâyihaları. Ankara: Murat Kitabevi.

Yıldırım, A. ve Şimşek, H. (2005). Sosyal Bilimlerde Nitel Araştırma Yöntemleri. Ankara:Seçkin Yayıncılık. 